\title{
Urban tourism - The impact of tourist accommodation in residential buildings at Vedado, Cuba
}

\section{Turismo de ciudad. Impacto del alojamiento turístico en edificaciones residenciales en El Vedado, Cuba}

\footnotetext{
Master of Science, Department of Design, Technological University of Havana CUJAE, La Habana, Cuba

2 Doctor of Technical Sciences, Department of Design, Technological University of Havana CUJAE, La Habana, Cuba

${ }^{3}$ Doctor of Sciences, Department of Design, Technological University of Havana CUJAE, La Habana, Cuba

${ }^{4}$ Architect, Engineering, Projects and Consulting Division, Specialized Engineers Services Company (ESINES), La Habana, Cuba

*ncolladoQarquitectura.cujae.edu.cu
}

Natali Collado Baldoquin ${ }^{1 *}$, Luis Alberto Rueda Guzmán² Dania González Couret ${ }^{3}$ and Karla Maria Lemus Mesa ${ }^{4}$

\section{ABSTRACT}

Insufficient requirements for the accommodation of tourists in houses in addition to the absence of comprehensive development plans have generated negative impacts in buildings and cities. The aim of this paper is to evaluate the main implications of tourist accommodations in residential buildings in El Vedado, Cuba. The methodology applied for this paper commenced through the use of spatial mapping to identify registered licenses for renting in a geographic information system. Field work was subsequently carried out and architectural surveys undertaken. Referrals were made to original design plans which were obtained in archives and surveys. Interviews were also conducted through the use of 35 case studies. Among the main results obtained were the characterization of the selected buildings and their territorial distribution. The conclusion was that the negative impacts included the loss of urban architectural values due to incorrect building modifications as well as increased energy consumption. Notwithstanding, the study revealed that the accommodation of tourists in houses has resulted in increases in family income, new complementary public services introduced and the substantial improvement of the technical constructive state of many residential buildings.

Keywords: Home stay accommodation, urban tourism, tourism impacts

\section{RESUMEN}

La falta de suficientes requerimientos en los alojamientos turísticos en viviendas y la carencia de planes de desarrollo integrales que las contemplen han generado efectos negativos en las edificaciones y las ciudades. Este trabajo tiene como objetivo analizar los principales impactos que se han generado en edificaciones residenciales con usos turísticos en El Vedado, Cuba. La metodología seguida parte de registrar en un sistema de información geográfica las licencias reconocidas para arrendar, luego se realizan trabajos de campo y levantamientos arquitectónicos, se consultan planos de los diseños originales en archivos y se realizan encuestas y entrevistas en 35 casos de estudios. Dentro de los principales resultados obtenidos se encuentra la caracterización de las edificaciones involucradas y la distribución territorial. Se concluye que dentro de los impactos negativos se encuentran la pérdida de los valores urbano-arquitectónico por incorrectas modificaciones a las edificaciones y el aumento de los consumos energéticos. De forma positiva se identifica que el alojamiento turístico en las viviendas ha permitido incrementar los ingresos de la familia, ha generado otros servicios complementarios y se ha mejorado el estado técnico-constructivos en gran parte de estas edificaciones.

Palabras clave: Alojamiento turístico en viviendas, turismo de ciudad, impactos del turismo 


\section{INTRODUCTION}

The so called urban or city tourism is currently one of the first modalities of this activity all over the world (Ashworth y Page, 2011; Gambarota y Lorda, 2018) and it constitutes one of the ways to promote development in many cities (Edwards, Griffin, y Hayllar, 2008). The multifunctional character of cities "per se" contributes to development in the same territorial space of different modalities of tourism such as cultural, historic, congress, business, sports, recreational, academic and shopping. (Rodríguez Vaquero 2009; Ashworth y Page, 2011). This vast amount of varied touristic opportunities generates the interest of a diverse cross-section of visitors and also determines selected preferences in their allocation.

The renting of rooms in residential buildings is a world trend which provides accommodation options in cities and is viewed as being more economical as opposed to accommodation in hotels. It allows for a more intimate interaction between the tourist and the residents (Choi et al. 2015; Bhuiyan, Siwar, y Ismail, 2013), an aspect very valued by visitors who want to learn from the local culture. The online divulgation platforms in the form of companies such as Airbnb have allowed for an accelerated growth of this type of accommodation as they contain as much allocation capacities and diversity as important world hotel chains (Zervas, Proserpio, y Byers, 2014; Choi et al. 2015). However, touristic allocation in residential spaces may also generate negative impacts for the city (Blanco Romero, Blázquez - Salom, y Canoves, 2018) and its buildings (Herrero Suárez, 2017), which according to Gutiérrez et al. (2017), have not been studied adequately.

The presence of foreign visitors is increasing in Cuba every year and tourism is considered to be the second source of income for the national economy. The country's Capital Havana is one of the prime destinations for visitors as the city possesses urban and architectural values having been recognised by UNESCO in the World Heritage List ${ }^{1}$. The city's rich cultural legacy is also promoted by diverse events such as Jazz Plaza, International Festivals of Ballet, Theatre and Latin-American Cinema, with the city in recent times observing the commemoration of its 500th anniversary.

The development and strengthening of the tourism sector in Cuba has led to increases in the type of accommo- dation capacities consisting of two fundamental alternatives which consists of the expansion of hotel chains and also the availability of housing rooms for rent. Whilst the first option has grown from investments managed by the Ministry of Tourism, the rental of residential spaces despite its regulation and control is still a spontaneous and less studied process. Today, data houses are collected by the Ministry of Labour and Social Security primarily for legal purposes in order to quantify and validate the taxes of tenants. The quantity and geographic location of the involved buildings are not registered neither is the use of leasing spaces. This information is also not known by institutions which are important determinants for the development of the territory.

This article intends to reflect on the impact which the use of residential spaces for touristic accommodation has had in buildings and their urban environment during the last years. The "Urban Zone of Historic and Cultural Value" of El Vedado in Havana (Cuba) has been utilized as the study area. Evidence has shown that the nature of the expansion of touristic accommodation in this area has been primarily for the purpose of satisfying cultural tourism.

\section{BIBLIOGRAPHIC REVIEW}

According to Richards (2003), the understanding and participation of visitors about the way of life and culture of a population or region is part of cultural tourism (Pereiro Pérez, 2009), whereby, "living as a local" has been a strategy to this tourist market in order to promote overnight stays in residential spaces. Mclntosh y Siggs (2005) in a study conducted explains that this type of small accommodation is characterized by its unique atmosphere, personalization, homelike ambience, warmth and added value (Agyeiwaah, 2019), qualities recognised as attractive for cultural tourists who visited cities.

To Agyeiwaah (2019), touristic accommodation in houses is one of the terms used to characterise a small lodging owned by a family also known as B\& $\mathrm{B}^{2}$, accommodation-house, guests-house, boutique hotel, among others. "Casa-particular" is the terminology specifically used in Cuba. This occurs when the owner lives together with the guest while the expression "hostel" and more recently

1 Historic Urban Centre Old Havana and its Fortress System (1982)

${ }^{2}$ Bed and Breakfast 
"boutique hotel", is used when the accommodation functions as a small hotel where the owner general does not reside.

Russo (2002), stated that tourist accommodation in residential spaces has a major potential to increase as opposed to hotel accommodation. This may be attributable to the fact that this type of accommodation does not require extensive available plots and buildings, a condition that is very restrictive in consolidated urban contexts as the historic centre and urban zones are endowed with touristic services. In addition, there are less operational regulations and standards governing the establishment of touristic accommodation in houses which makes it easier for this type of accommodation to be established. This is further justified by the advantages derived which mainly consists of better economic prices, greater effectiveness of commercialization platforms such as P2P, and to allow for direct connectivity with tourists and local inhabitants, which has comprehensively resulted in this type of accommodation option evolving into a growing and developing sector for many of the main cities around the world.

This accommodation alternative has notably boosted the local economy due to the incomes and job opportunities that it generates (Gutiérrez et al. 2017). Although there are a group of owners who use this type of business to complement other sources of income, there is also a business sector originating from distant areas resulting in much of their earnings being transferred to the places where they reside (Yrigoy, 2017).

Tourism in the city generates increased demand on public spaces and infrastructure services since their extensive use by foreign visitors compounds the usual activities of inhabitants (Ashworth y Page, 2011; Gutiérrez et al. 2017; Blanco Romero, Blázquez - Salom, y Canoves, 2018). This exerts more pressure on traditional residential sectors, since the development of this activity has not been planned integrally, to allow for the critical analysis of pertinent information which consists not only of the total number of tourists who arrive at the territory but also where they spend the night and what are the most common activities that they engage in. The development of touristic leases in residential buildings has also been one of the recognized causes of gentrification processes either as a result of the increments from housing rentals or because of the increases in living standards in the region (Blanco Romero, Blázquez - Salom, y Canoves, 2018; Herrero Suárez, 2017). Those problems are exacerbated when there is greater influx of visitors, (mass tourism), and their impacts have been evaluated in cities such as Venetia, Barcelona and Paris. Despite Cuba receiving between 14 and $40 \%$ of visitors with respect to these cities in 2018, it is recommended to study this problem in territories which depend on this activity (Russo, 2002).

At the scale of the buildings, it has also been noted that problems exist between the inhabitants and the tourists such as noise, dirt or the scarce adoption of neighbour life norms (Herrero Suárez, 2017). Some studies have also indicated that the lack of sufficient requirements relating to the hygiene and safety of the spaces as well as their management not only affects the owner, but also the image of the touristic city (Eva Desdentado Daroca, Fernando Díaz Vales, y Manuel Lucas Durán, 2018).

The inclusion of tourist accommodation in residential buildings located in context with urban and patrimonial values generates other contradictions. On one hand, it is an alternative to increase the value of the use of goods and to improve the economic possibilities to maintain and rescue part of the estate. However, reconditioning of those spaces to meet the activity requirements and demand results in increases in living standards, added to the overexploitation of the buildings which may result in losing their present values (Menéndez, 2017).

In Cuba, the possibility of renting rooms in houses was legalized again in 1984, and since then it has acquired a mainly touristic character, compared to the diverse options to rent residential spaces existing before 1959 (Herrera Linares, 2013). The laws and standards related to this renting process has been modified since then and at the same time the interest of the population to obtain legal permission has fluctuated. The modifications currently allow for the inclusion of gastronomic services in the accommodation offer and to lease, not only rooms but also entire houses and spaces (Ministerio de Trabajo y Seguridad Social, 2018). According to the Ministry of Tourism, 93731 rooms available for international tourism in Cuba were accounted for in 2018, $20 \%$ of which were located in residential buildings. («Turismo cubano por buen camino» 2019). As 
stated by Simoni (2016), the private services for tourism in the island (among which renting rooms are included) are changing the physic and socioeconomic landscape of the country; however, related published researches are not focused on the physical impact of this activity (Duffy y Kline, 2018).

\section{METODOLOGY}

As the study area, the 505 ha belonging to the "Zone of historic-cultural value of El Vedado" 3 have been taken. It is located to the North of "Plaza de La Revolución" municipality, in Havana, capital of Cuba (See fig. 1).

Figure 1. Location of the study area

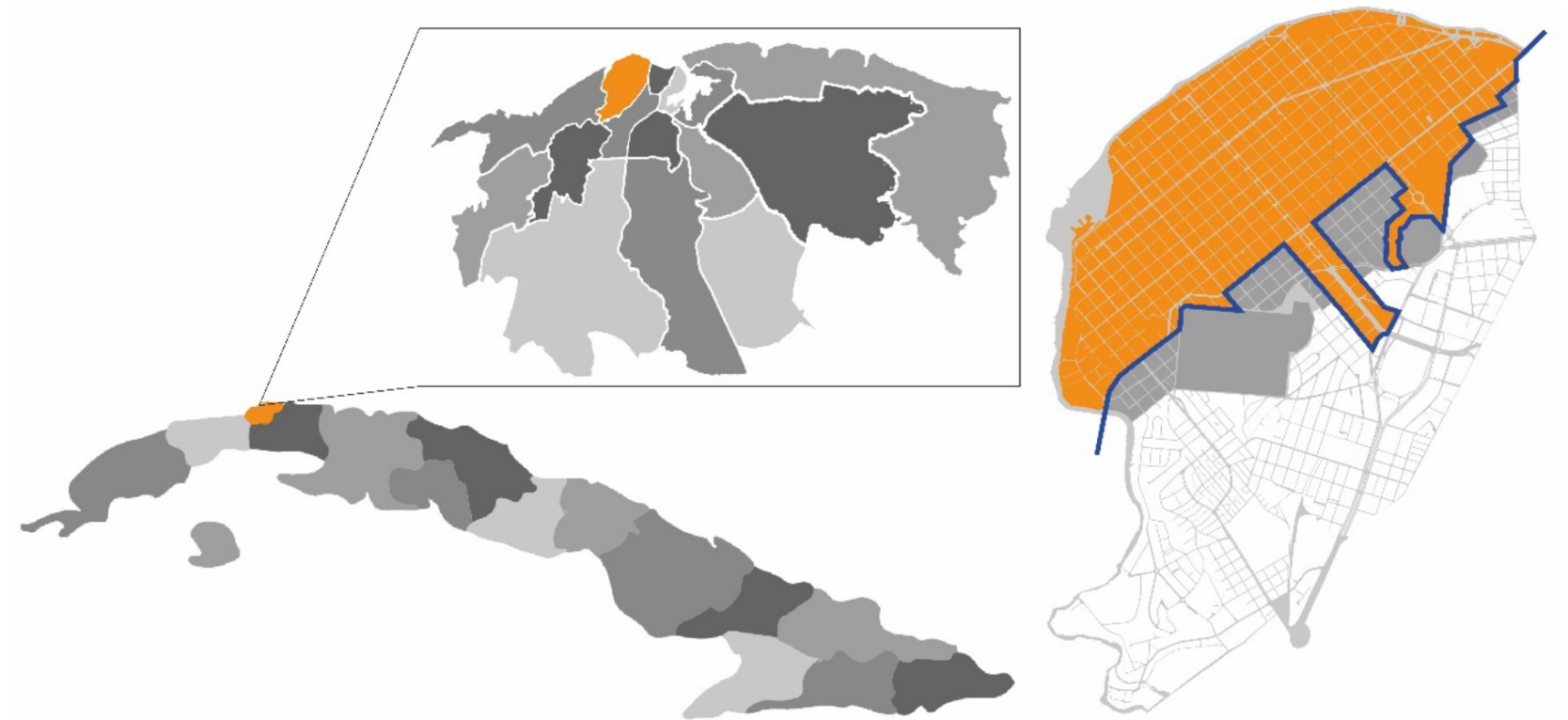

Since 1999 the National Commission of Monuments recognized that this territory has historic and cultural values, as it constitutes "a vanguard example of urban planning" and has "numerous buildings of a high patrimonial value" (Lechuga, 2007). Two main city centres of services are currently located in this area (See fig. 5) and there also exists an important network of theatres, cinemas, night clubs and gastronomic services (Lechuga, 2007). Simultaneously advantageous to this area, is the convenient accessibility to the zone made possible by the main streets (Línea, Malecón y Calzada) connecting to other zones of touristic attractions such as the historical centre "Old Havana" and the beaches of the East.

As a basis for this work, data regarding existing licenses to rent a house (totally or partially) has been taken from the municipal office of the Ministry of Labour and Social Security in October 2018. This institution collects information about each legal permission to rent as well as the addresses, owner information and type of lease, according to the denomination of the regulation for own accord working of 2018 (Chapter II, article 31): housing, rooms and spaces (Ministry of Labour and Social Security, 2018). The research is focused on touristic accommodation, whilst the permission to rent only spaces were not taken into account since they are mainly dedicated to gastronomic or commercial services.

The first stage of the work consisted of the spatial registration of each license for renting in the area, using the tool QGIS 3.04, in order to determine how many buildings contain rented spaces and their territorial distribution.

During the second step, field work was conducted to obtain a photographic survey of each building, identifying the destination of each rented house or room. This final aspect was not included in the initial available information and it allowed for the rejection of leasing dedicated to other services which differed from accommodation. The information 
about these buildings exist on the "Provincial Physical Planning Archive" and the "National Archive of Cuba" was also consulted to obtain their original conditions.

The third step included a more detailed analysis of single family houses in which 3 or more rooms are rented, with up to 2 owners ${ }^{5}$, of which only $38 \%$ of the cases (35 buildings) who met the requirements were willing to collaborate. The intention of this step was to determine the touristic use of the housing (precedence of the guests' interests for visiting the country/territory, common activities of the visitors in the city and the buildings, as well as their schedule); characteristics and modifications of the buildings and their immediate environment (spatial distribution, transformations, and technical constructive features). For this purpose, surveys were conducted regarding indoor housing and interviews conducted with the owners and employees. Questions were also asked regarding energy consumption (type and quantity of consumed energy and the equipment as well as the use of renewable energies), since this work is part of a major research conducted to transform residential buildings with touristic accommodation into "Nearly Zero Buildings".

Finally, the information was processed and analysed in order to determine the main impact of tourism use on these buildings and the territory where they are located.

\section{RESULTS}

El Vedado currently has 8052 rooms dedicated to tourist accommodation from which $68 \%$ are located on 1721 residential buildings. The remaining $32 \%$ are part of the 9 hotels placed on the territory, with a range of between 158 and 572 lodgings each (See fig. 2).

Figure 2. Distribution of hotels and residential buildings with tourist accommodation in El Vedado



\footnotetext{
${ }^{5}$ This sample was selected because the owners of singe family houses have more freedom to modify the buildings, since they have more rooms for accommodation it is evident the interaction between the housing and the rent, and having less different owners means the building has been less fragmented.

${ }^{6}$ The European directive (Directiva 2010/31/UE) define Nearly Zero Buildings as those with a high energy efficiency and covering in a great extent its low energy demand by renewable sources from the site or nearby.
} 
The owners live in their houses or apartments in the 55\% of the 5510 bedrooms in such a way that the tourist coexist with the local family, sharing spaces of common use such as the living and dining room. The remaining $45 \%$ of the bedrooms are placed in houses totally rented for tourist accommodation in which two main trends are observed. In the first instance the house is transformed into a small hotel, offering restaurant and bar facilities while the kitchen as well as other spaces is not accessible to the visitor. The second type of accommodation results from housing totally rented for a family or a group of friends who use it as a common residence, but only for a few days.
Current regulations do not set the maximum amount of spaces to lease, despite there being major restrictions when intending to rent more than 4 rooms. This fact added to the increment of taxes according to the amount of rooms leads to a majority of licenses to rent very few rooms. However, different entrepreneurs with diverse licenses coexist in the same building. The figure 3 shows that in $72 \%$ of the buildings there are between 1 and 3 rooms rented, and in $25 \%$ of them there are between 4 and 10 . Only $2 \%$ contain between 11 and 20 rooms and $1 \%$ more than 20 , making it 51 rooms which the present maximum capacity in the same building (See fig. 3 ).

Figure 3. Distribution of buildings according to the amount of rented rooms

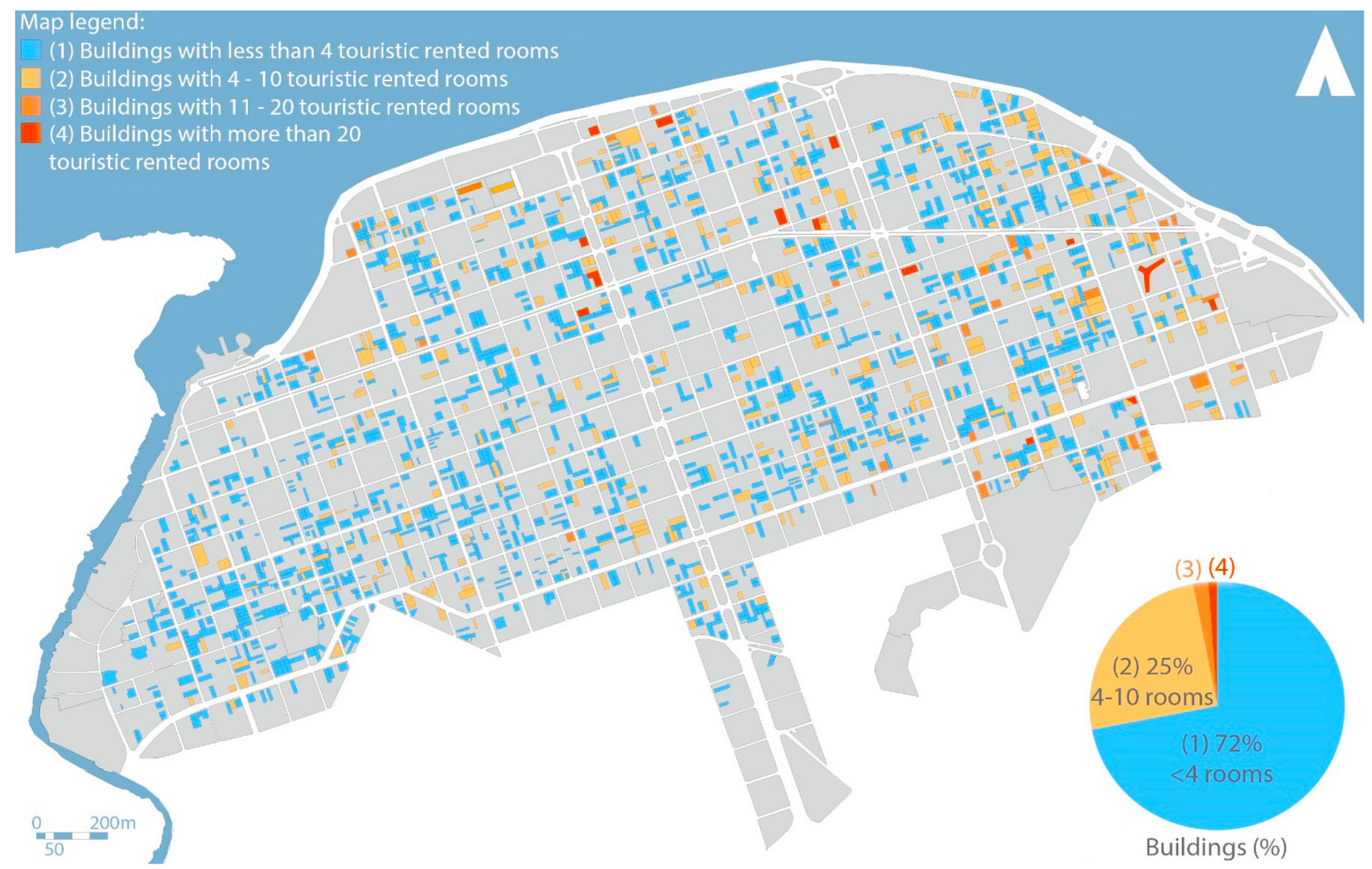

It is forbidden to increase the habitational capacity in those houses dedicated to this activity so that the maximum depends to a great extent on the original design of the building. The Urban Regulations for EI Vedado (RUV) identifies 6 building typologies: the single family house in the corner or as a "villa", the twin single family house, the common buildings, the "cuarterías - ciudadelas", the multifamily buildings and the towers (Colectivo de autores, 2007). The field work allowed for confirmation that the defined typologies excluded other existing buildings, hence a new classification was proposed for this work. Four main groups are considered which are the low building, the apartment building, the tower and the interior building (See Table 1) 


\section{RIAT}

Table 1. Typology classification of residential buildings with tourist lodging in El Vedado
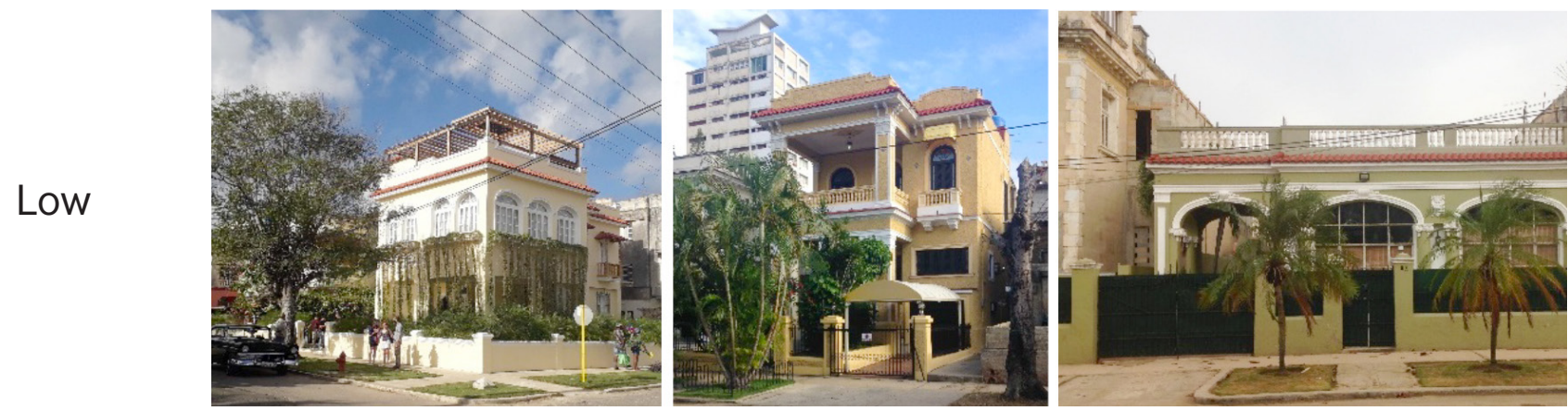

As "low building" is considered all edification up to 2 stories, or exceptionally more, but whose volume correspond to a single family house. Part of this group are those classified as village twin and commons by the urban regulations.

Interior


It is considered "interior building" to those which don't face the street, but its main facade looks to a corridor. "Ciudadelas" and other humble housing that substitute them, as well as apartment buildings located to the interior of the block.

Apartment
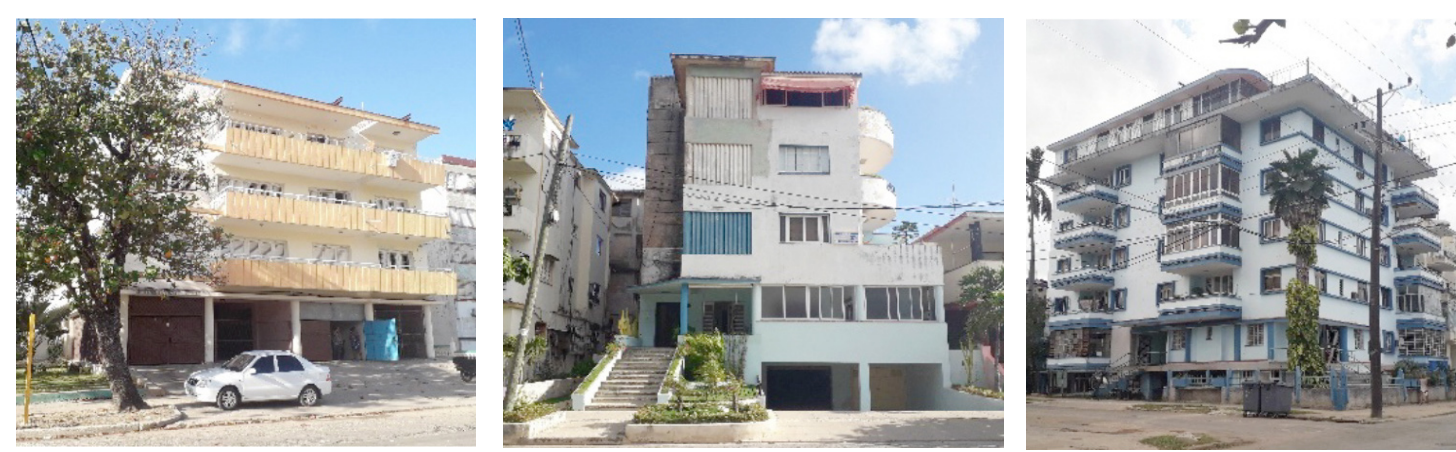

Apartment buildings are those between 3 and 10 stories in which several housing share common spaces and services (as circulations). 


\section{RHAT}
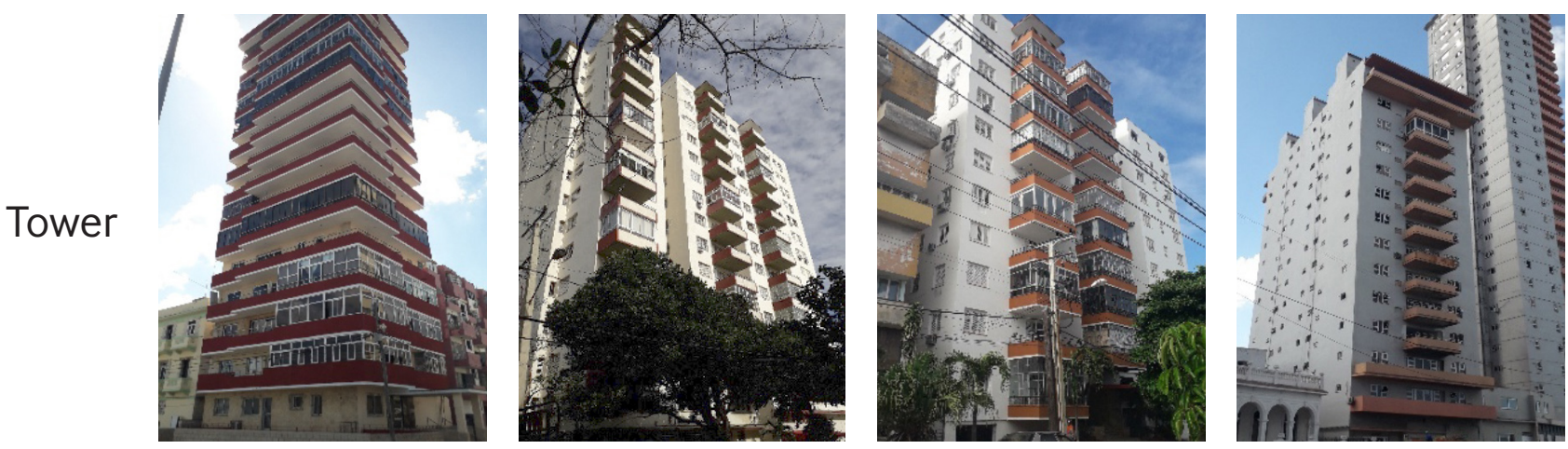

It is considered as "tower" all apartment buildings higher than 10 stories.

There are located on apartment buildings the $55 \%$ of the rental rooms, which constitute $51 \%$ of the total. The other $32 \%$ of the rooms are dispersed in 1755 low buildings which represent $45 \%$ of the studied edifices. The towers constituting $2 \%$ of the constructions, contain $12 \%$ of the available rooms. The less representative typology is the building located in the interior of the block, which represents $2 \%$, with only $1 \%$ of lodgings (See fig. 4). All the formerly mentioned buildings containing more than 20 rental rooms are towers and in a minor extent, large apartment buildings.

Figure 4. Residential building typologies with touristic accommodation in El Vedado






\section{RIAT}

The touristic accommodation in houses is very dispersed in the territory. However, the tourist habitational density (rooms/hectare) in residential buildings demonstrates that there are more of them near to the sea (to the North of Línea Street and to the East of G Avenue) (See fig. 5). It is mainly because the tallest buildings are located in these sectors and the sea constitutes an important attraction in the zone.

Some urban sectors, despite having touristic interest and easy accessibility, do not possess the same concentration of touristic lodgements. Such is the case of G Avenue and Paseo street, where despite containing highly hierarchized urban ways, their main buildings are used as governmental institutions or embassies resulting in limited availability of residential buildings within the area. Similarly, the first block towards the sea are occupied mainly by hotels and recreational or sports facilities.

Figure 5. Density of touristic habitational rental (rooms/hectare) in El Vedado. City centres and subcentres present on the area according to the urban regulations

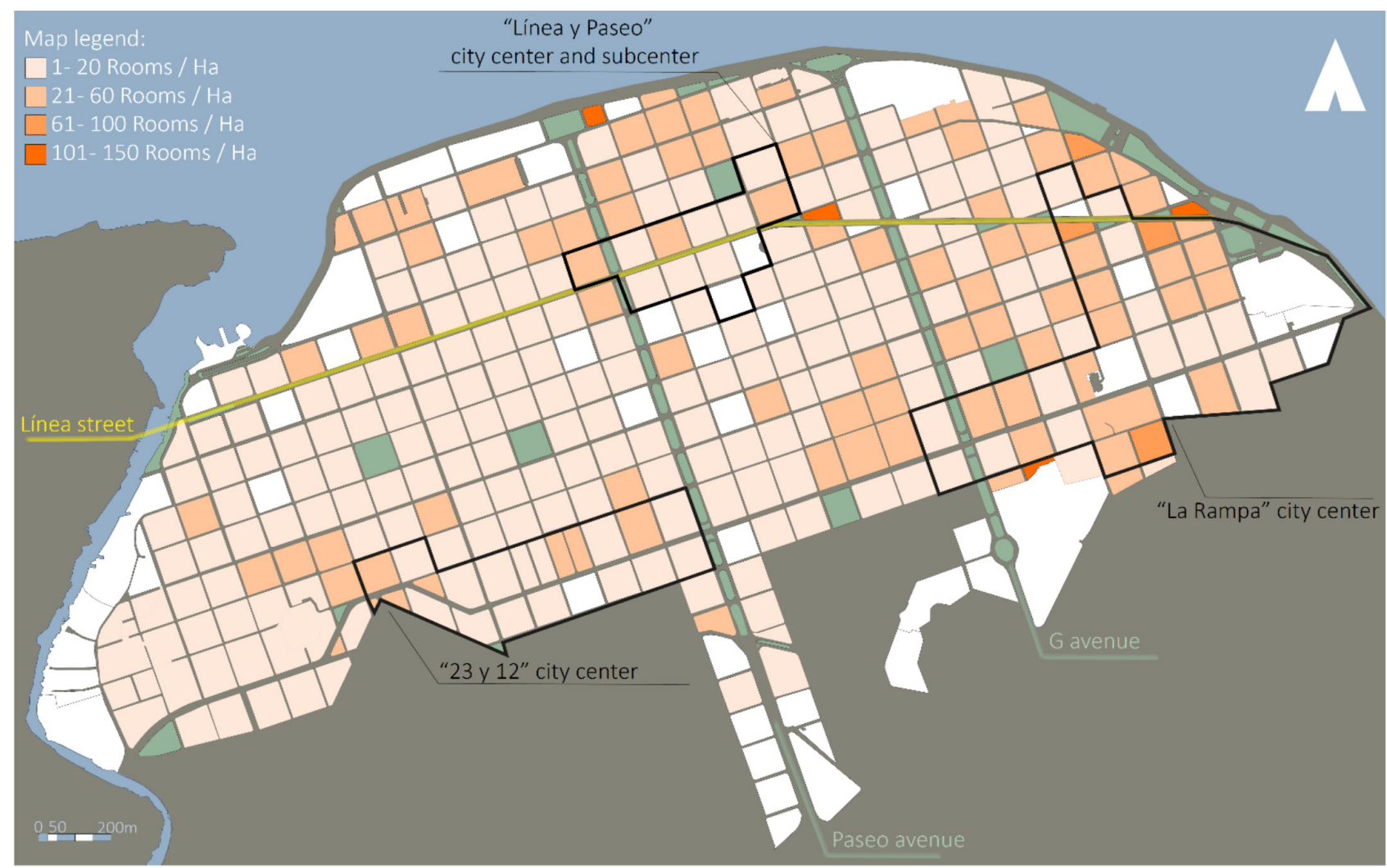

According to the interviews conducted, the main source of tourism arrivals is Europe and the United States of America. During most recent years, increases have been recorded in tourism arrivals from Latin America. This pattern is similar to that registered at the national level, where the USA was the second source of visitor arrivals until June $2019^{7}, 27 \%$ of tourist arrivals were received from Europe and 23\% from Central and South America («Turismo international. Indicadores seleccionados. Enero - Junio 2019»
2019). From the interviews conducted with housing owners, the main purpose for visitor arrivals to Havana were mainly to "know the people and the city" and only in two cases revealed that persons were interested in working or studying. The main guest routine consists of going out in the morning on tours and returning to take a bath and to rest. Visitors sometimes go out again about $6 \mathrm{pm}$ for dinner and to visit recreational centres while others return after dinner to sleep.

\footnotetext{
7 The firs country emitting tourism to Cuba is Canada, despite it is known that the main interest of this market is sand and beach.
} 
The main spaces used by the tourists are the rooms and during socialization moments the dining room, exterior galleries or terrace are also utilized. It is offered breakfast and sells beverages in the $52 \%$ of the accommodation, however, it seems to be a complimentary service which may likely increase since it has recently been authorized by the 2018 legislation (Ministerio de Trabajo y Seguridad Social, 2018).

The conceived transformations for the houses has been already made according to the $90 \%$ of interviewed tenants. The main causes of modifications have been to increase rooms for rent and sanitary services, to improve the technical and constructive stage of the building and to achieve better standards of comfort and beauty. This housing reconditioning results in impacts both positive and negative on the associated buildings.

The main transformations affecting the recognised elements of value which also violate urban regulations are closing porches to enlarge indoor spaces, occupying part of the garden area with structures mainly for parking, construction of new rooms in back or lateral corridors, added floors without an integral conception, high and opaque fences, and substitution of the original carpentry (See Fig. 6, 7 y 8 ).

Figures 6, 7 y 8. External transformations in housing with tourist accommodation in El Vedado.
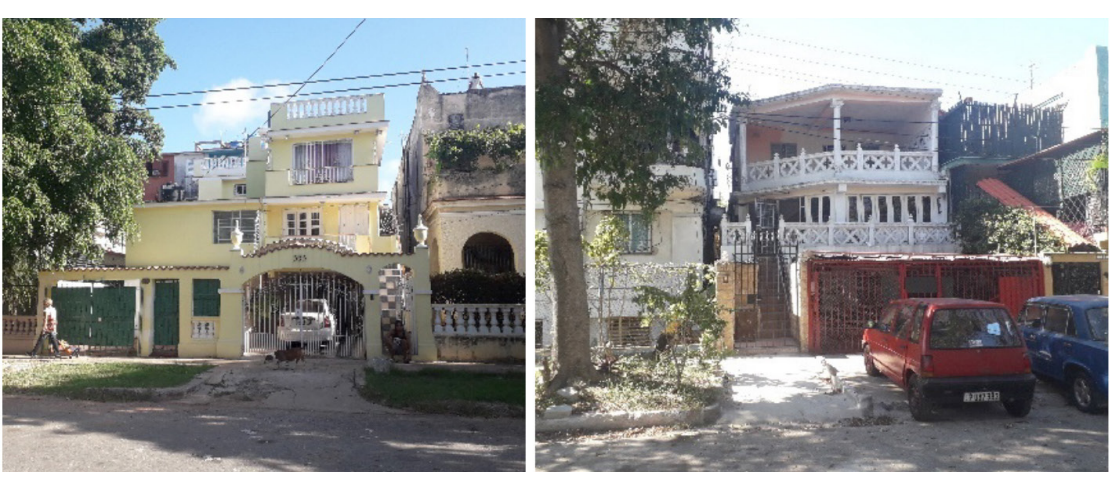



Among the main indoor modifications are reducing the ceiling height, addition of new bathrooms or dividing the existing ones, closing common spaces to be transformed into bedrooms, as well as redistributing functions (among the more common are moving the kitchen and closing the living room to be used as a bedroom). Some of these modifications besides affecting the interior spatiality, have generated other conflicts with respect to air exchange and increasing indoor temperature, since, for example, part of these transformations have eliminated access to the outdoors and the natural ventilation of some spaces.

In certain cases, the built interventions have eliminated transformations that undermine the spatial and aesthetic values of the buildings as well as to rescue the garden design. It has been understood that reconditioning these buildings for touristic rental and to be successful and competitive depends on realizing harmonic modifications on the existing buildings (See fig. 9, 10 y 11).

Figures 9,10 y 11 . Touristic lodgements that have respected the urban image with recognized value



\section{DISCUSSION}

Renting houses and rooms are currently an important alternative in the touristic system of El Vedado, not only because of the major availability of bedrooms with respect to the hotels on the territory, but because it is the accommodation option complementing much of the requirements of city tourism as a modality. The accommodation prices are more economical than those of the hotel chains since they are smaller and the services offered are more personalized. In most of the accommodations the tourists reside with the family, which results in a quicker connection and understanding of the local customs. Researches about private renting in Cuba confirm the interest of the tourist to overnight in houses, since $89 \%$ of visitors are willing to repeat and to recommend this type of accommodation due to its quality, efficiency, speedy and professionalism (Silveira Pérez, Cabeza Pullés, y Fernández-Pérez, 2016).

Today, a few rooms per house are used to rent, mainly due to the high taxes and the requirements imposed by the different entities authorizing licenses to rent rooms and houses. To limit the amount of housing with touristic purposes is a measure similar to others promoted by local government in Amsterdam, Paris, London, Milano, Toronto, Vancouver, Nueva York and San Francisco. Other decisions have also been made in these cities so as to restrain the duration of touristic rent, the amount of guests per house and to define territories where rental is allowed (Guttentag, 2015; Blanco Romero, Blázquez - Salom, y Canoves, 2018; EY, 2015). All these actions are intended to eliminate the negative impacts mentioned, such as the diminishing of residential spaces and the displacement of the native population.

Despite the fact that an application for a licence has to be evaluated by numerous Cuban institutions, in the interviews the owners indicated that the main requirements imposed on them were related to the housing ownership and the sanitary licence to operate a food related business. This implies that few considerations are given to the impact that such changes can have on the esthetical, technical as well as the overall environmental impacts of such building modifications. Other researchers have indicated the importance of imposing more conditioning factors to this type of accommodation, either for protecting the visitor and the touristic image of the territory or to diminish the environmental and energy impact of these buildings (Román Márquez 2013, 2018). The standards to be achieved could be promoted by incentives such as tax reductions, and subventions and loans as opposed to strict compliance regulations.

This type of business has generally contributed to improvements in the domestic economy, although there are cases where the owner resides outside the country, resulting in the non-realization of a direct local impact ${ }^{8}$. As evidenced in the interviews, the tourists seek accommodation in order to overnight since visitors prefer to partake in other activities traditionally developed in hotels such as gastronomy, recreation and shopping as different services within the city provide the ability to provide more diverse options and specialized offers. This also strengthens the urban economy as other local business are promoted based on the increased accommodation to touristic demands, such as cafeterias, bars, bike rentals, guiding and transportation services (Silveira Pérez, Cabeza Pullés, y Fernández-Pérez, 2016). However, in other contexts it is difficult to distinguish between the touristic and non- touristic uses of the city (Ashworth y Page, 2011), since the salary disparity existing in Cuba clearly evidence those services directed to the foreigners with higher incomes than the local people. This accentuates internal socio-cultural conflicts which should subsequently be integrally analysed through other researches.

As it pertains to construction modifications, it is evident that there exists a disparity in what is considered aesthetically adequate by the owners. For some sectors of the population who possess adequate economic resources, to them, the use of excessive textures and finishing is considered beautiful. Those owners tend to imitate building typologies that may not necessarily respond to their immediate urban context. Often times, foreign references such as large glass windows, or the use of decorative elements taken from other styles and eras (for instance, the use of chromatic finishes) characterize the interventions that those owners make on existing buildings, thus resulting in great deviations for their traditional in the context. This results in the loss of values, falsifying and or diminishing the authenticity of the site which is vital to the sustainability of cultural tourism (Grande Ibarra, 2001; Pereiro Pérez, 2009).

\footnotetext{
${ }^{8}$ In the same way, it always generates some Jobs for maintenance, cleaning and marketing.
} 
Modifications made for the purposes of major comfort have been mainly based on an acclimatized space, and very few of them have potentiated the relationship between indoors and outdoors as well as the passive cooling by natural or even mechanical ventilation. In addition, other modifications have worsened the thermal indoor environment such as the replacement of the traditional "French windows" 9 and closing porches and galleries with glass panes, increasing indoor temperatures and limiting air flow. Despite this, some interventions have potentiated the use of vegetation as a shadow element as well as generating terraces with double green roofs which allows for concurrent use of the roof which provides shadow over an element with a high incident solar radiation.

Knowledge of the location and intensity of use of these buildings is essential to develop the infrastructure that sustains them. The residential sector is responsible for $60 \%$ of the electricity consumption in the country and the buildings in this analysis are among the most consuming ( $\mathrm{Se}$ gunda comparecencia especial del Presidente Miguel Díaz Canel» 2019). All the rented rooms use air conditioning ${ }^{10}$, in addition to having more electrical equipment than a conventional housing (television set and freezer in each room). Water tanks have increased in those residential houses since the water supply is not constant in the territory to simultaneously cover the high demand. Adding the function of touristic lodgement to the residential capacity means that there will be resulting increments in the frequency of some activities which require water consumption such as washing and cleaning as well as the engagement in other foreign habits and customs which results in increases in water and electricity consumption. Energy demand of these lodgements is therefore significant as this necessitates greater knowledge, planning and management of the energy sector by the territorial governments.

For the purpose of this analysis, only those lodgements which contain legal approval to rent were analysed as a data source in addition to the rooms defined by the tenants to be used for touristic purposes. However, from a further detailed analysis it is presumed that a greater quantity of rooms than those declared are really utilized for tourism in addition to the existence of housing rental rooms without official licenses. Based on this, the pheno- menon is greater than this study and the impacts have a greater magnitude.

The proportion of new hotels under construction indicates that the state will continue building large and luxury complexes with multiple recreational and public services in tall buildings to take advantage of the sights to the city and the sea. Despite the fact that the process to approve licences has been modified, there is still room for improvement to allow all involved institutions to be impacted in a positive way to consolidate the territory and its touristic system. During recent years it has been perceived as a new approach towards the private sector and as an alternative with a varied and heterogeneous context, but nonetheless has to be considered in the development plans, given its integral growth in order to avoid negative impacts globally such as gentrification.

\section{CONCLUSION}

In an urban area as central as El Vedado in Havana, the rental of houses is the alternative to satisfy the cultural tourists who are attracted by more affordable prices and the possible contact to the local people. The evidence has shown that this type of accommodation that this visitor requires is a small lodgement essentially composed of a few rooms with bathrooms and spaces to socialize preferably located in the outdoors such as terraces and porches. The territorial distribution of lodgements in residential spaces is very disperse in El Vedado, despite the existence of zones with major amounts of lodgements due to the architectural typology as well as the closeness and sea view as an important attraction in the area.

El Vedado constitutes one of the territories with the greatest amount of private touristic lodgements, comprising of $22.6 \%$ of the total rooms for rent in the country in 2018. $72 \%$ of the buildings consisting of 1 and 3 bedrooms are rented and only $1 \%$ has more than 20 bedrooms. This is as a consequence of the architectural typologies present on the zone which are mainly low buildings making it difficult to achieve higher densities of touristic rented habitat. National regulations also limited this practice to be extended mainly because of the increased taxes for rented rooms. The presence of this type of lodgement, complimented

\footnotetext{
Window of foldable panes with adjustable wooden louvers and an interior glass closing. Its use is extended in most of these buildings since it allows to protect against sun and offer multiple options of opening and control of outdoors conditions.

${ }^{10}$ It is not common to have all bedrooms with air-conditioning, and even when it exists, its used is normally limited to the night period.
} 
by urban services, has allowed for a boost in the economy and the physical environment. However, some modifications made on expansions in the form of a greater number of rooms and bathrooms as well as the aesthetic reconditioning of the houses have resulted in negative impacts on the historical and cultural values identifying the territory. The indoor thermal environment is also impacted resulting from the accommodation and services requirements which subsequently increases energy consumption in the residential sector.

Regulations related to touristic rentals in houses have been modified and diverse institutions have been involved in the process to approve licences for rent. However, requirements are still minimum and the information related to leasing are not managed with the importance it requires to boost the integral and sustainable development of the territory.

\section{Acknowledgements}

This work is part of a doctoral research supported by the VLIR-UOS project (CU2017TEA435A103). The contribution of architecture students from CUJAE in part in the field work is appreciated. The assistance of colleagues with the management of QGIS and English corrections is gratefully acknowledged.

\section{REFERENCES}

Agyeiwaah, Elizabeth (2019) Exploring the Relevance of Sustainability to Micro Tourism and Hospitality Accommodation Enterprises (MTHAEs): Evidence from Home-Stay Owners. Journal of Cleaner Production 226:159-71. https://doi.org/10.1016/j. jclepro.2019.04.089.

Ashworth, Gregory, y Stephen J. Page (2011) Urban Tourism Research: Recent Progress and Current Paradoxes. Tourism Management 32:1-15.

Bhuiyan, Anowar Hossain, Chamhuri Siwar, y Shaharuddin Mohamad Ismail (2013) Socio-Economic Impacts of Home Stay Accomodations in Malaysia: A Study on Home Stay Operators in Terengganu State. Asian Social Science 9:42-49. http://dx.doi. org/10.5539/ass.v9n3p42.

Blanco Romero, Asunción, Macia Blázquez - Salom, y Gemma Canoves (2018) Barcelona, Housing
Rent Bubble in a Tourist City. Social Responses and Local Policies. Sustainability 10. https://doi. org/10.3390/su10062043.

Choi, Ki-Hong, Joohyun Jung, Suyeol Ryu, Su-Do Kim, y Seong-Min Yoon (2015) The Relationship between Airbnb and the Hotel Revenue: In the Case of Korea. Indian Journal of Science and Technology 8:1-8. https://doi.org/10.17485/ijst/2015/v8i26/81013.

DIRECTIVE 2010/31/EU OF THE EUROPEAN PARLIAMENT AND OF THE COUNCIL of 19 May 2010 on the energy performance of buildings (recast) (2010) http://eur-lex.europa.eu/legal-content/ EN/TXT/PDF/.

Duffy, Lauren, y Carol Kline (2018) Complexities of Tourism Planning and Development in Cuba. Tourism Planning \& Development 15:3:211-15. https://doi. org/10.1080/21568316.2018.1440830.

Edwards, D., T. Griffin, y B. Hayllar (2008) Urban tourism research: developing an agenda. Annals of Tourism Research 35:1032-52.

Eva Desdentado Daroca, Fernando Díaz Vales, y Manuel Lucas Durán (2018) Los problemas jurídicos del "Alojamiento colaborativo": un estudio interdisciplinar. Fundación Alternativas.

EY (2015) Alojamiento turístico en viviendas de alquiler: Impactos y retos asociados. Exceltur.

Gambarota, Daniella Melisa, y María Amalia Lorda (2018) Análisis de los atractivos turísticos de una ciudad intermedia: El caso de Bahía Blanca, Argentina. Revista Interamericana de Ambiente y Turismo 14:135-60.

Grande Ibarra, Julio (2001) Análisis de la oferta de turismo cultural en España. Estudios turísticos 150:1540.

Gutiérrez, Javier, Juan Carlos García-Palomares, Gustavo Romanillos, y María Henar Salas-Olmedo (2017) The Eruption of Airbnb in Tourist Cities: Comparing Spatial Patterns of Hotels and Peer-toPeer Accommodation in Barcelona. Tourism Management 62:278-91. http://dx.doi.org/10.1016/j. tourman.2017.05.003. 
Guttentag, Daniel (2015) Airbnb: Disruptive Innovation and the Rise of an Informal Tourism Accommodation Sector. Current Issues in Tourism 18: 12:1192-1217. https://doi.org/10.1080/13683500.2013.827159.

Herrera Linares, Santiago (2013) La vivienda en Cuba nuevo enfoque legal -. La Habana: Editorial de Ciencias Sociales.

Herrero Suárez, Carmen (2017) Las viviendas de uso turístico: ¿El enemigo a abatir? Reflexiones sobre la normativa autonómica en materia de alojamientos turísticos. Revista de Estudios Europeos no. 70:147-58.

Lechuga, Vivian, ed. (2007) Regulaciones urbanísticas Ciudad de La Habana. El Vedado. Municipio Plaza de la Revolución. Ediciones Boloña \& Ediciones Unión.

Menéndez, Madeline (2017) El Vedado habanero. Amenazas y oportunidades sobre su arquitectura residencial. En X Encuentro internacional Ciudad, Imagen y Memoria, Santiago de Cuba.

Ministerio de Trabajo y Seguridad Social (2018) Resolución no. 11/2018. Reglamento del Ejercicio del Trabajo por Cuenta Propia. GOC-2018-475-EX35.

Muñoz, Oscar (2019) Barcelona recibe más turistas extranjeros y dejan más dinero. La Vanguardia. 18 de marzo de 2019. https://www.lavanguardia.com/ local/barcelona/20190318/461083674799/turismo-turistas-barcelona.html.

Pereiro Pérez, Xerardo (2009) Turismo Cultural. Uma visão antropológica. PASOS. Revista de Turismo y Patrimonio Cultural 2:307p.

QGIS (2019) 16 de septiembre de 2019. https://qgis. org/es/site/.

Rodríguez Vaquero, J. E. (2009) Turismo urbano y sistema territorial. Almería, modelo emergente. Nimbus 23-24:171-81.

Román Márquez, Alejandro (2013) Las viviendas particulares dedicadas a la actividad de alojamiento turístico. Su exclusión de la ley de arrendamientos urbanos. Revista Internacional de Doctrina y Jurisprudencia.
(2018) Planificación urbanística del turismo: la regulación de las viviendas de uso turístico en Madrid y Barcelona. Revista de estudios de la Administración Local y Autonómica Nueva Época 10:22-39. https://doi.org/10.24965/reala. v0i10.10566.

Russo, Antonio Paolo (2002) The Vicious Circle of Tourism Development in heritage cities. Annals of Tourism Research 29-1:165-82.

Segunda comparecencia especial del presidente Miguel Díaz Canel(2019) Mesa Redonda. La Habana. http:// www.cubadebate.cu/noticias/2019/09/12/cuba-no-esta-paralizada-contamos-con-una-estrategia.

Silveira Pérez, Yahilina, Dainelis Cabeza Pullés, y Virginia Fernández-Pérez (2016) Emprendimiento: perspectiva cubana en la creación de empresas familiares. European Research on Management and Business Economics 22:70-77. http://dx.doi. org/10.1016/j.iedee.2015.10.008.

Statista Research Department (2019) Number of Tourist Arrivals in Paris Hotels 2006-2018. Statista. 25 de septiembre de 2019. https://www.statista.com/ statistics/468164/number-tourist-arrivals-hoteIs-paris/.

Turismo cubano por buen camino (2019) Juventud Rebelde. 2 de enero de 2019. http://www.juventudrebelde.cu/cuba/2019-01-02/turismo-cubano-por-buen-camino.

Turismo internacional. Indicadores seleccionados. Enero - Junio 2019 (2019) La Habana: Oficina Nacional de Estadística e Información. República de Cuba.

Yrigoy, Ismael (2017) Airbnb en Menorca: ¿Una nueva forma de gentrificación turística? Localización de la vivienda turística, agentes e impactos sobre el alquiler residencial. Scripta Nova. Revista Electrónica de Geografía y Ciencias Sociales Vol. XXI. (Num. 580).

Zervas, G., D. Proserpio, y J. Byers (2014) The rise of the sharing economy: Estimating the impact of Airbnb on the hotel industry. 